\title{
Dermatology
}

Dermatology 2010;220:55-56

DOI: $10.1159 / 000249512$

\section{Thomas More Syndrome}

Ralph M. Trüeb, Alexander A. Navarini

Department of Dermatology, University Hospital of Zurich, Zurich, Switzerland

\section{Key Words}

Canities subita $\cdot$ Marie Antoinette $\cdot$ Thomas More

'Canities subita' designates the condition in which scalp hair suddenly turns white $[1,2]$. The synonymous term 'Marie Antoinette syndrome' has been coined for this disorder, in relation to the account of the ill-fated Queen Marie Antoinette of France (1755-1793), whose hair allegedly turned white the night before her last walk to the guillotine during the French Revolution [3, 4]. Although the actual incidence is probably rare, sudden whitening of the hair has been used as a literary stylistic means to demonstrate extreme psychological stress [5]. The first documented case of sudden hair whitening can be traced back to the Talmud (83 AD), which describes a scholar who was appointed chief of the main Israeli Talmudic academy at the young age of 17 years. Upon his wife's concern that he looked too youthful for the position, he developed 18 rows of white hair [6]. The Jewish rabbi, physician and philosopher Maimonides (1135-1204) suggested that this was the result of strenuous studying. History also records that the hair of the English martyr Sir Thomas More (1478-1535) turned white overnight in the Tower of London before his execution [7] (fig. 1a, b). Sir Thomas More, also known as Saint Thomas More, was an English lawyer, author and statesman who in his lifetime gained a reputation as a leading Renaissance humanist scholar and occupied many public offices, including Lord Chancellor from 1529 to 1532 . He was beheaded in 1535 after having refused to sign the Act of Supremacy that declared King Henry VIII Supreme Head of the Church of England over the Pope. In 1935, four hundred years after More's death, Pope Pius XI canonized him in the Roman Catholic Church. More modern accounts refer to the turning white of hair in survivors of bomb attacks during World War II.

We observed a 56-year-old man with sudden total whitening of scalp hair and eyebrows within weeks (fig. 1c, d). He was otherwise completely healthy and had not experienced any stressful event.

Today, the syndrome is interpreted as an acute episode of diffuse alopecia areata in which the very sudden 'overnight' whitening of hair is caused by the preferential loss of pigmented hairs in this supposedly immune-mediated disorder [8]. As early as 1901, immunology research pioneer and Nobel Prize Laureate (1908) in Medicine for his work on phagocytosis, Elie Metchnikoff (1845-
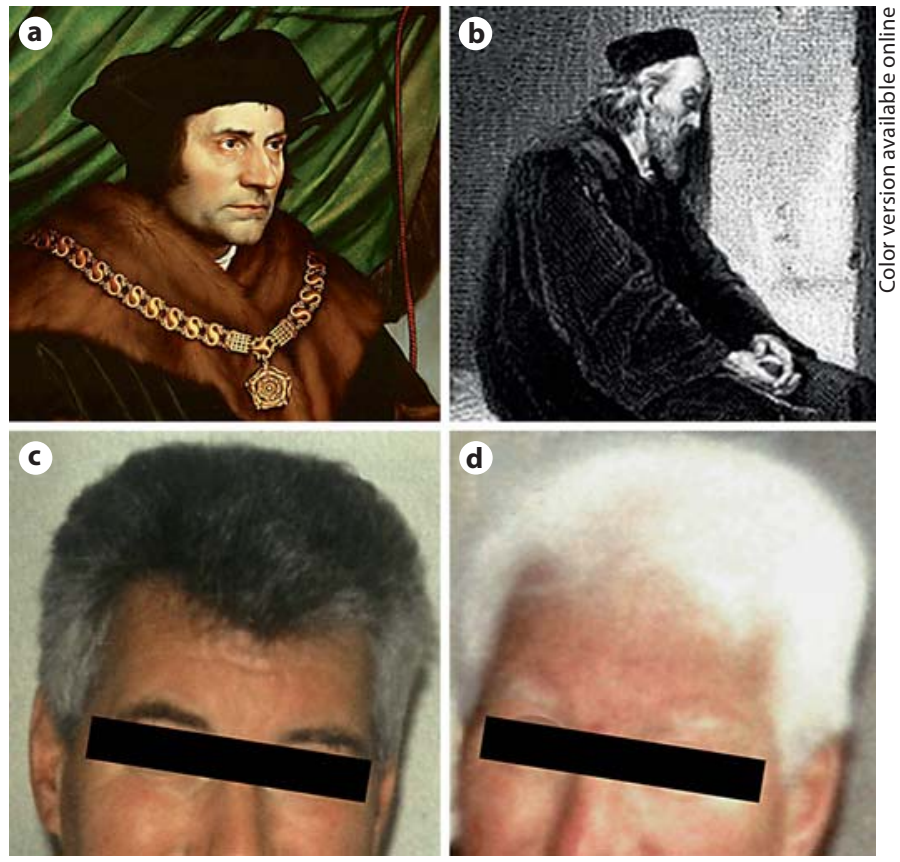

Fig. 1. a Sir Thomas More, dated 1527, by Hans Holbein the Younger (1497/98-1543). The Frick Collection, New York. b Sir Thomas More reflecting in his prison cell. Source: Aubrey, William Hickman Smith. The National and Domestic History of England (1878). c Pigmented scalp hair and eyebrows. d Six weeks after the onset of rapid whitening of both scalp hair and eyebrows.

1916), believed that whitening of hair was related to pigment absorbed and carried away by phagocytes he observed in the vicinity of dystrophic hair follicles and called 'pigmentophages' [9]. In 1981, Guin et al. [10] reported a lady whose hair turned white over 3 months with hair thinning but no patches of alopecia. Immunofluorescence studies demonstrated immune deposits along the follicular epithelium suggesting an underlying immunological mechanism. Finally, case reports of sudden canities in association with easily plucked hairs, exclamation mark hairs and patchy alopecia typical of alopecia areata [11], and in coexistence with other presumably autoimmune phenomena, such as vitiligo [12], support the immune theory. Ultimately, these observations have led some authorities to speculate that the autoimmune target in alopecia areata may even be related to the hair follicle melanin pigment system [13]. McBride and Bergfeld [14] described mosaic hair color changes in two patients with extensive alopecia areata and suggested that these processes may result from localized immunological reactions against hair follicle melanocytes in a mul-

\section{KARGER}

(ㄷ) 2009 S. Karger AG, Basel

Fax +41613061234 E-Mail karger@karger.ch www.karger.com 
tifocal pattern with subsequent changes in hair color. In contrast to total whitening of hair, this mechanism would account better for the pattern of ' 18 rows of white hair' originally described in the Talmud.

Although Marie Antoinette has been chosen as eponym for the syndrome, presumably out of dermatological gallantry, Saint Thomas More, who turned white in 1535, ought to have the right of seniority over the Queen of France who succumbed to the same fate in 1793. Since there seems to be no other particular reason for favoring Marie Antoinette over Thomas More, out of fairness, it would seem appropriate to use the term 'Marie Antoinette syndrome' for the condition afflicting women and 'Thomas More syndrome' for men.

\section{References}

1 Hoffmann E: Sudden turning gray of the hair caused by fright, canities subita psychogenica. Z Haut Geschlechtskr 1957;22:74-78.

2 Helm F, Milgrom H: Can scalp hair suddenly turn white? A case of canities subita. Arch Dermatol 1970;102:102-103.

3 Garcia-Hernandez MJ, Camacho FM: Atypical forms of alopecia areata; in Camacho FM, Randall VA, Price VH (eds): Hair and Its Disorders. Biology, Pathology and Management. London, Dunitz, 2000, pp 236ff.

4 Mani MK: The Marie Antoinette syndrome. Natl Med J India 2007;20: 35.

5 Bahmer FA: Das Phänomen des plötzlichen Ergrauens in der Ballade 'Die Füsse im Feuer' von Conrad Ferdinand Meyer. Hautarzt 2002;53: 492-494.
6 Goldenhersh M: Rapid whitening of the hair first reported in the Talmud: possible mechanisms of this intriguing phenomenon. Am J Dermatol 1992;14:367-368.

7 Jelinek J: Sudden whitening of the hair. Bull NY Acad Med 1972;48: 1003-1013.

8 Tobin DJ, Paus R: Graying: gerontobiology of the hair follicle pigmentary unit. Exp Gerontol 2001;36:29-54.

9 Metchnikoff E: On the process of hair turning white. Proc R Soc Lond 1901;69:156.

10 Guin JD, Kumar V, Petersen BH: Immunofluorescence findings in rapid whitening of scalp hair. Arch Dermatol 1981;117:576-578

11 Navarini AA, Nobbe S, Trüeb RM: Marie Antoinette syndrome. Arch Dermatol 2009;145:656.

12 Ephraim A: On sudden or rapid whitening of the hair. AMA Arch Dermatol 1959;79:228-236.

13 Paus R, Slominski A, Czarnetzki BM: Is alopecia areata, an autoimmune response against melanogenesis-related proteins, exposed by abnormal MHC class I expression in the anagen hair bulb? Yale J Biol Med 1993;66:541-554.

14 McBride AK, Bergfeld WF: Mosaic hair color changes in alopecia areata. Cleve Clin J Med 1990;57:354-356.

Prof. Ralph M. Trüeb

Department of Dermatology, University Hospital of Zurich Gloriastrasse 31, CH-8091 Zurich (Switzerland)

Tel. +41 4425530 79, Fax +41 442554431

E-Mail ralph.trueeb@usz.ch 